\title{
Clinical and Demographic Characteristics of the Culture Results of Patients Applying to the Emergency Department
}

\section{Acil Servise Başvuran Hastaların Kültür Sonuçlarının Klinik ve Demografik Özellikleri}

\section{(D) Şakir Ömür Hıncal11, (D) Mehmet Akif Karamercan², (D) İsmail Ödemiş3}

${ }^{1}$ University of Health Sciences Turkey, Bağcılar Training and Research Hospital, Clinic of Emergency Medicine, İstanbul, Turkey

${ }^{2}$ Gazi University Faculty of Medicine, Department of Emergency Medicine, Ankara, Turkey

${ }^{3}$ Büyükçekmece Mimar Sinan State Hospital, Clinic of Emergency Medicine, İstanbul, Turkey

\section{Abstract}

Objective: Culture examination is a frequently used diagnostic method in emergency departments. This study was performed to investigate the frequency of culture examinations that were sent from the emergency department and also the rate of positive results and the most frequently isolated pathogens.

Method: This is a retrospective cohort study. We retrospectively investigated the cultural results of the patients who were admitted to the emergency department between $1^{\text {st }}$ Jan 2016 and 315t March 2017. The demographic datum, medical diagnosis, the culture type, and the results were recorded from the hospital records.

Results: Totally 70,934 culture tests were sent from 45,100 patients between study dates. $1.1 \%$ of the cultures were sent from the emergency department. There was colonization at $16.8 \%$ of the cultures; this ratio was $33.6 \%$ in the cultures that were sent from the emergency department. The cultures were more frequently positive in emergency medicine when we compared them to those in the whole hospital. The positivity rate was higher in wound and abscess cultures but very low in gaita cultures.

Conclusion: The further detailed studies about the cultures sent from the emergency department on the basis of a specific disease and antibiotic resistance will be instructive about prophylactic antibiotic use in the emergency department.

Keywords: Bacteremia, culture analysis, emergency department, microbiology

\section{öz}

Amaç: Kültür muayenesi, acil servislerde sıklıkla kullanılan bir tanı yöntemidir. Bu çalışma, acil servisten gönderilen kültür incelemelerinin sıkığını, ayrıca olumlu sonuçların oranını ve en sık izole edilen patojenleri araştırmak amacıyla yapıldı.

Yöntem: Bu çalışma retrospektif bir kohort çalışmasıdır. 1 Ocak 201631 Mart 2017 tarihleri arasında acil servise başvuran hastaların kültür sonuçlarını geriye dönük olarak incelendi. Hastane kayıtlarından demografik veriler, tıbbi tanı, kültür tipi ve sonuçlar kayıt altına alındı.

Bulgular: Çalışma tarihleri arasında 45.100 hastadan toplam 70.934 kültür testi gönderildi. Kültürlerin \%1,1i acil servisten gönderildi. Kültürlerin $\% 16,8$ 'inde kolonizasyon vardı. Acil servisten gönderilen kültürlerde bu oran \%33,6 idi. Acil tıpta kültürler, tüm hastaneyle karşılaştırdığımızda daha sık pozitifti. Pozitiflik oranı yara ve apse kültürlerinde daha yüksek, gaita kültürlerinde ise çok düşüktü.

Sonuç: Acil servisten belirli bir hastalık ve antibiyotik direnci temelinde gönderilen kültürlerle ilgili daha detaylı çalışmalar, acil serviste profilaktik antibiyotik kullanımı konusunda yol gösterici olacaktır.

Anahtar kelimeler: Acil servis, bakteriyemi, kültür analizi, mikrobiyoloji

Address for Correspondence: Şakir Ömür Hıncal, University of Health Sciences Turkey, Bağcılar Training and Research Hospital, Clinic of Emergency Medicine, İstanbul, Turkey

E-mail: omur.hincal@gmail.com ORCID: orcid.org/0000-0002-2116-7710 Received: 25.09.2020 Accepted: 29.10.2020

Cite this article as: Hıncal ŞÖ, Karamercan MA, Ödemiş i. Clinical and Demographic Characteristics of the Culture Results of Patients Applying to the Emergency Department. Bagcilar Med Bull 2020;5(4):216-223

(-) Copyright 2020 by the Health Sciences University Turkey, Bagcilar Training and Research Hospital Bagcilar Medical Bulletin published by Galenos Publishing House. 


\section{Introduction}

Infectious diseases are among the frequent applications to the emergency register. There are many admissions to emergency departments from infections such as pneumonia, urinary system infection, soft tissue infection, meningitis, sepsis, and neutropenic fever. In these patients, it is important to take a culture in the emergency department to support the diagnosis and guide the appropriate antibiotic treatment. It is especially important to start antibacterial therapy urgently in some conditions, such as sepsis, meningitis, and neutropenic fever. It is essential to take samples such as blood, cerebrospinal fluid (CSF), and urine in emergency services, to deliver them to the laboratory in a short time, to reproduce in their cultures, and to initiate effective antimicrobial treatments according to the result.

Blood cultures are a frequently used diagnostic method in emergency departments, but the necessity of this is discussed in the literature (1). Although guidelines do not provide much information about when to take a blood culture sample,Infectious Disease Society of America (IDSA) offers suggestions on this subject (2). However, as the most appropriate time, the period when the concentration of microorganisms is highest in the blood is the 30-60 minute period before fever. However, since it is not always possible to predict this period in many patients, blood culture should be taken as soon as possible after the fever begins to rise. Blood cultures should be taken before antibiotic therapy is initiated.

In this study, we aimed to evaluate the positivity rates and the number of culture tests requested from the emergency department and to identify the most frequently isolated pathogens.

\section{Materials and Methods}

\section{Study Design and Population}

This study was planned retrospectively. It was started after the approval of the Ethics Planning Board numbered 2017/582 at the 49th Board Meeting held on 13.06.2017 from the Ethics Committee of the Turkish Republic Ministry of Health, University of Health Sciences Turkey, İstanbul Bağcllar Training and Research Hospital. Results from patients who applied to the Emergency Medicine Clinic between January 1, 2016, and March 31, 2017 were analyzed retrospectively. The demographic data of the patients, the diagnosis made in the emergency department, the place where the culture samples were taken, and the culture results were obtained from the medical records of the patients in the electronic information system of our hospital.

\section{Statistical Analysis}

The data obtained in the study were analyzed with SPSS 20.0 for the Windows package program. Of the continuous variables, those with normal distribution were expressed as mean \pm standard deviation, and those without normal distribution were expressed as median (minimummaximum). Normal distribution was evaluated byhistogram and the Kolmogorov-Smirnov test. Categorical variables were expressed as numbers (percent). The significance of the difference between the averages of the two groups was evaluated using the Mann-Whitney $U$ test and the Student t-test in normal distributions. The significance of the difference between the groups in categorical variables was evaluated with the chi-square test. $\mathrm{P}<0.05$ level was considered statistically significant.

\section{Results}

During the study period, 70,934 samples were sent from 45,100 patients. Seven hundred seventy four (1.1\%) of the examinations were requested by the emergency department. Reproduction was detected in $16.8 \%$ $(n=11,907)$ of all cultural studies. In cultures sent from the emergency department, reproduction was detected in 260 samples (33.6\%), $2.2 \%$ of all cultures detected reproduction were sent from the emergency department. When cultures requested from all hospitals and emergency services were compared, positivity was found more frequently in emergencies $(\mathrm{p}=0.001)$.

During the study, growth was detected in a total of 260 culture samples from 236 patients. From the blood, CSF, and urine samples of the patients, reproduction was observed in only one variety from 214, 2 separate from 20 , and 3 separate culture samples from 2 of them. $64.2 \%(n=167)$ of patients with reproduction were women. The average age was $46.56 \pm 21.48$ years; The median age was 46 years $(0-89$ years). The mean age of women ( $43.0 \pm 21.3$ years) was lower than that of men $(52.9 \pm 20.5$ years $)(p<0.001)$.

Wound culture and urine culture were the most common examples of cultures sent from the emergency department (Table 1). The positive rates of culture samples sent from the emergency department both in the emergency department and in all hospital samples are shown in Table 1. The positivity rate is seen mostly in catheter cultures in the emergency room and wound cultures throughout the 
hospital. The least positive rates were seen in feces cultures in both the emergency room and all hospital-wide samples.

Table 2 shows the distribution of pathogens detected in reproduction in culture. The most frequently detected pathogen was E. coli $(\mathrm{n}=67,25.8 \%)$ followed by $S$. aureus $(\mathrm{n}=52,20.0 \%)$.

Table 3 lists the most frequently isolated pathogens from all cultures. The most common pathogen in culture samples taken after abscess drainage was $S$. aureus $(\mathrm{n}=13,41.9 \%)$, followed by $S$. pyogenes $(\mathrm{n}=4,12.9 \%)$. Reproduction was observed in three of the sputum culture samples, and $P$. aeruginosa, $P$. fluorescens, and $S$. schleiferi reproduction

Table 1. Reproduction rates of culture types sent by the emergency department in all hospitals and emergency rooms

\begin{tabular}{lllll} 
& \multicolumn{2}{l}{ All patients } & \multicolumn{2}{c}{$\begin{array}{l}\text { Emergency } \\
\text { department }\end{array}$} \\
\cline { 2 - 5 } & $\mathbf{n}$ & $\begin{array}{l}\text { Positive } \\
\text { rate (\%) }\end{array}$ & $\mathbf{n}$ & $\begin{array}{l}\text { Positive } \\
\text { rate (\%) }\end{array}$ \\
\hline Abscess (aerob) culture & 374 & $57.5 \%$ & 33 & $63.6 \%$ \\
Abscess (aerob) culture & 405 & $29.4 \%$ & 2 & $50.0 \%$ \\
Fecal culture (aerob) & 1.048 & $4.2 \%$ & 19 & $10.5 \%$ \\
Urine culture (aerob) & 55,034 & $15.0 \%$ & 386 & $19.2 \%$ \\
Blood culture (aerob) & 2.514 & $22.9 \%$ & 46 & $37.0 \%$ \\
Blood culture (anaerobe) & 1.601 & $20.5 \%$ & 28 & $32.1 \%$ \\
Catheter tip culture & 331 & $42.9 \%$ & 5 & $100.0 \%$ \\
Sterile body fluid (aerob) & 493 & $25.2 \%$ & 66 & $27.3 \%$ \\
Wound culture (aerob) & 2.493 & $64.3 \%$ & 121 & $65.3 \%$ \\
\hline
\end{tabular}

were detected. Only two of the stool culture samples had reproduction and Salmonella reproduction was detected in both. The most frequent pathogen in urine culture samples was $E$. $\operatorname{coli}(\mathrm{n}=46,59.0 \%)$, followed by K. pneumoniae $(\mathrm{n}=13$, $16.7 \%)$. The most common pathogen in culture samples taken from the catheter tip was $S$. aureus $(\mathrm{n}=4,66.7 \%)$. In blood culture samples, the most common pathogen in the aerobic culture was $S$. aureus $(\mathrm{n}=7,31.8 \%)$ and the most frequent pathogen in the anaerobic culture was $S$. aureus $(\mathrm{n}=4,33.3 \%)$. This was followed by $E$. coli $(\mathrm{n}=3,25.0 \%)$ in aerobic culture and $S$. hominis $(\mathrm{n}=6,27.3 \%)$ in anaerobic culture. The most common pathogen in culture samples taken from sterile body fluids was $S$. aureus $(\mathrm{n}=5,16.0 \%)$, followed by $E$. coli and $S$. agalactiae $(\mathrm{n}=4,16.0 \%)$. The most common pathogen in the culture samples taken from the wound was $S$. aureus $(\mathrm{n}=17,21.0 \%)$, followed by S. epidermidis $(\mathrm{n}=13,16.0 \%)$.

\section{Discussion}

The time it takes to get the results of the culture causes empirical treatment to be applied in some cases. This increases the importance of the regional antibiotic profile and resistance rates. In our study, $2.2 \%$ of the culture examinations evaluated in the microbiology laboratory were requested by the emergency department. In the study of Ece Terek and Tunçel Başoğlu (3), which included 348 isolates (37.1\%) produced from 937 urine samples sent to a university hospital microbiology laboratory, this rate

Table 2. Pathogen distribution detected in cultures

\begin{tabular}{|c|c|c|c|c|c|}
\hline & $\mathbf{n}$ & $\%$ & & $\mathbf{n}$ & $\%$ \\
\hline Acinetobacter baumannii & 2 & 0.8 & Salmonella species & 2 & 0.8 \\
\hline Acinetobacter baumannii \& calcoaceticus complex & 1 & 0.4 & Staphylococcus aureus & 52 & 20.0 \\
\hline Candida albicans & 4 & 1.5 & Staphylococcus gallinarum & 1 & 0.4 \\
\hline Enterobacter aerogenes & 3 & 1.2 & Staphylococcus haemolyticus & 5 & 1.9 \\
\hline Enterococcus faecium & 4 & 1.5 & Staphylococcus saprophyticus & 1 & 0.4 \\
\hline Escherichia coli & 67 & 25.8 & Staphylococcus schleiferi & 2 & 0.8 \\
\hline Klebsiellaoxytoca & 2 & 0.8 & Staphylococcus xylosus & 1 & 0.4 \\
\hline Klebsiella pneumoniae & 21 & 8.1 & Streptococcus agalactiae & 5 & 1.9 \\
\hline Pseudomonas aeruginosa & 9 & 3.5 & Streptococcus mitis & 1 & 0.4 \\
\hline Pseudomonas fluorescens & 1 & 0.4 & Streptococcus pyogenes & 9 & 3.5 \\
\hline Pseudomonas species & 1 & 0.4 & Streptococcus species & 1 & 0.4 \\
\hline
\end{tabular}


was reported as $5.9 \%$. In our study, growth was detected in $16.8 \%$ of all culture tests sent by all departments of the hospital. In the cultures sent by the emergency service, $33.6 \%$ growth was detected. Similar to our study, in a study by Yücel et al. (4), in which the results of all cultures sent to patients who applied to a university hospital emergency service were examined, it was reported that reproduction was detected in $17 \%$ of the cultures sent by the emergency service. In our study, it was seen that the cultures sent by the emergency department were higher in the positive rate. It was thought that the probable reason for this might

Table 3. The most frequently isolated pathogens in cultures

n $\%$

\begin{tabular}{|c|c|c|}
\hline \multicolumn{3}{|l|}{ Abscess (aerop) culture } \\
\hline Staphylococcus aureus & 13 & 41.9 \\
\hline Streptococcus pyogenes & 4 & 12.9 \\
\hline Escherichia coli & 3 & 9.7 \\
\hline \multicolumn{3}{|l|}{ Sputum culture (aerob) } \\
\hline Pseudomonas aeruginosa & 1 & 33.3 \\
\hline Pseudomonas fluorescens & 1 & 33.3 \\
\hline Staphylococcus schleiferi & 1 & 33.3 \\
\hline \multicolumn{3}{|l|}{ Fecal culture (aerob) } \\
\hline Salmonella species & 2 & 100 \\
\hline \multicolumn{3}{|l|}{ Urine culture (aerob) } \\
\hline Escherichia coli & 46 & 59 \\
\hline Klebsiella pneumoniae & 13 & 16.7 \\
\hline Enterococcus faecalis & 4 & 5.1 \\
\hline \multicolumn{3}{|l|}{ Catheter tip culture } \\
\hline Staphylococcus aureus & 4 & 66.7 \\
\hline Enterococcus faecalis & 1 & 16.7 \\
\hline Escherichia coli & 1 & 16.7 \\
\hline \multicolumn{3}{|l|}{ Blood culture (aerob) } \\
\hline Staphylococcus aureus & 7 & 31.8 \\
\hline Staphylococcus hominis & 6 & 27.3 \\
\hline Staphylococcus epidermidis & 3 & 13.6 \\
\hline \multicolumn{3}{|l|}{ Blood culture (anaerobe) } \\
\hline Staphylococcus aureus & 4 & 33.3 \\
\hline Escherichia coli & 3 & 25 \\
\hline Staphylococcus epidermidis & 2 & 16.7 \\
\hline \multicolumn{3}{|l|}{ Sterile body fluid (aerob) } \\
\hline Staphylococcus aureus & 5 & 20 \\
\hline Streptococcus agalactiae & 4 & 16 \\
\hline Escherichia coli & 4 & 16 \\
\hline \multicolumn{3}{|l|}{ Wound culture (aerob) } \\
\hline Staphylococcus aureus & 17 & 21 \\
\hline Staphylococcus epidermidis & 13 & 16 \\
\hline Escherichia coli & 10 & 12.3 \\
\hline
\end{tabular}

have been because patients who were considered to have infections in our emergency department generally gave cultures in the outpatient clinic conditions but only if there was high suspicion and if prophylactic antibiotic treatment would be initiated in a short time.

In the study, $64.2 \%$ of the patients in whom cultures were sent by the emergency department were women; the average age was $46.56 \pm 21.48$ years; the median age was 46 years (range 0-89). Yücel et al. (4) reported that their average age was $52 \pm 21$ years (in the range of $17-100$ ) and the numbers of women and men were equal in their studies. In the study conducted by Yürümez et al. (5), similar to our study, they reported that the mean age was $45.6 \pm 19.5$ years, and $54.4 \%$ of the patients were male. In the study conducted in Germany, in which 18,785 culture samples were included, $78 \%$ of the patients were female and the average age of all patients was $62 \pm 24$ years (6). The average age in Germany is almost the highest among those in the European Union countries, so the average age was considered to be higher in hospital applications and accordingly in the samples taken. (7). Likewise, regional differences within the country can change the average age of the patient population.

In our study, in the general distribution of the pathogen detected in culture growth, the most common pathogen was $E$. coli $(25.8 \%)$ followed by $S$. aureus $(20.0 \%)$. In the study of Yücel et al. (4), similar to our study, they found the most frequent growth of $E$. coli with $47.2 \%$ when all samples were taken into consideration. In the study conducted by Çetin et al. (8) in a university hospital in one year, which involved intensive care patients, a reproduction rate of 28.8\% was detected in 1859 culture samples taken from intensive care patients, and the most frequent pathogens were reported as coagulase-negative streptococci. In the study of Ertürk et al. (9) conducted similarly in a hospital in a university, reproduction rate of $33 \%$ was detected in the samples sent from patients in the intensive care unit. Of the microorganisms that grew, 152 (51\%) were Gram-negative, 102 (34\%) were Gram-positive bacteria and $43(14 \%)$ were yeast (9). All hospitals have infection control committees under the control of the Ministry of Health and carry out studies to prevent bacterial colonization, especially in intensive care units. However, certain pathogens can be seen in certain services $(10,11)$. Accordingly, microorganisms and culture positivity rates were thought to change.

In the study, the positivity rate of sputum culture was $29.4 \%$ throughout the hospital and $50.0 \%$ in the samples sent by the emergency department. In the retrospective study of Yücel et al. (4), in which 1.485 patient samples from the 
microbiology laboratory of a university for a period of 15 months were included, reproductive rate of sputum cultures sent by the emergency department was reported as $43 \%$ (4). In our study, reproduction was observed in three of the sputum culture samples, and $P$. aeruginosa, $P$. fluorescens and $S$. schleiferi reproduction were detected in these. In the study of Yücel et al. (4) reproduction was reported in three of the sputum cultures, with methicillin-resistant coagulase-negative staphylococcus, $P$. aeruginosa, and $S$. aureus (4). In the study conducted by Çetin et al. (8), a reproduction rate of $30 \%$ was detected in sputum culture samples taken from intensive care patients and the most common breeding pathogens were reported as Enterobacteriaceae. In the studies of Talay et al. (12), it was aimed to determine the resistance profile of antibiotics against the factors reproduced in the nonspecific culture results of the patients hospitalized with the lower respiratory tract infection and to investigate the empirical treatment approaches in these cases, and 41 patients with reproduction from 84 cases were evaluated. Reproducing microorganisms were reported as $S$. pneumonia (39\%), $K$. pneumonia $(31.7 \%)$, and $P$. aeruginosa (19.5\%), respectively. In our study, sputum culture was desired very little. Comparison studies have been seen at higher rates compared to our study since there are cultures sent from chest disease outpatient clinics. In our study, it is not possible to comment on the most common pathogen since the number of cases is very few. Also, the most frequently detected pathogens in studies have been reported as $S$. pneumonia, K. pneumonia, and P. aeruginosa.

In the study, the positivity rate of stool culture was $4.2 \%$ throughout the hospital and $10.5 \%$ in the samples sent by the emergency department. Only two of the stool culture samples had reproduction and Salmonella reproduction was detected in both. In the study of Yücel et al. (4), reproduction rate of stool cultures sent by the emergency department was reported as $0 \%$ in the study. Güney and Başustaoğlu (13). reported that an enteric pathogen was found in $6.6 \%$ of the total 379 stool cultures and the most common of these were campylobacter $(56 \%)$ and salmonella $(44 \%)$. The fecal culture was found to be very positive both in our study and in previous studies. When we evaluated our study and other studies together, it was thought that it would be appropriate to evaluate whether the cultures determined to be so positive were necessary.

Studies have shown that the factors that cause urinary tract infections are Gram-negative rods and enterococci, often caused by fecal flora (14). In the study of Ece Dağlar et al. (15), urine samples sent to Tavşanlı and Uşak State Hospital Microbiology Laboratories were retrospectively analyzed, standard microbiological methods were used for the isolation of bacteria from clinical samples, and antimicrobial sensitivity was investigated by disk diffusion method. They detected reproduction in $8.3 \%$ of these urine samples; $84.9 \%$ of the reproducing bacteria were Gram-negative and $15.1 \%$ were Gram-positive bacteria. The most frequently isolated Gram-negative bacteria were $45.1 \%$ E. coli and the most common Grampositive bacteria were reported as $10.9 \%$ Enterococcus sp (15). In the study conducted by Çetin et al. (8), a reproduction rate of $30.2 \%$ was detected in urine culture samples sent from intensive care patients and the most frequent pathogens were E. coli and Candida spp. reported to follow. In our study, the urinary culture positivity rate was $15.0 \%$ throughout the hospital and $19.2 \%$ in the samples sent by the emergency department. Yücel et al. (4) reported reproduction rate as $18 \%$ in the administration cultures sent by the emergency department in the study. The most common pathogen in urine culture samples was $E$. coli (59.0\%), followed by $K$. pneumonia (16.7\%). In the study of Ece Terek and Tunçel Başoğlu (3), the most frequent strains detected in urine cultures were $52 \%$ E. coli, followed by $E$. faecalis with $15.5 \%$ (3). Urine culture is a frequent examination both in emergency departments and other units. In general, E. coli is more frequently isolated. In our study, results consistent with the literature were obtained.

In the study, the catheter tip culture positivity rate was $42.9 \%$ throughout the hospital and $100 \%$ in samples sent by the emergency department. In the study of Yücel et al. (4), reproduction rate of catheter tip cultures sent by the emergency department was reported as $50 \%$. In the culture samples taken from the catheter tip, the most common pathogen was $S$. aureus (66.7\%). In the study of Ergin et al. (16) in which intravascular catheter cultures were evaluated in patients in intensive care units, it was reported that the catheter culture was $35 \%$ positive and the most common pathogens were coagulase-negative staphylococci $(14 \%)$ and methicillin-resistant $S$. aureus (2\%). Again, in the study of Çetin et al. (8), a reproduction rate of $31 \%$ was determined in urine culture samples sent from intensive care patients and the most common reproductive pathogens were coagulase-negative streptococci and it was reported that $S$. aureus followed it. It was reported in the study of Sünbül et al. (17) that were reproduced in the catheter culture at the rate of $61 \%$ in pediatric intensive care patients, and 
the most common pathogens were coagulase-negative staphylococcus and methicillin-resistant $S$. aureus. In our study, $S$. aureus was detected most frequently in samples sent from the catheter tip, regardless of coagulase and methicillin resistance.

Blood cultures are a common diagnostic method in emergency departments, but the need for this is discussed in the literature (1). Although guidelines do not provide much information about when to take a blood culture sample, IDSA offers suggestions on this subject (2). In our study, the aerobic blood culture positivity rate was $22.9 \%$ throughout the hospital and $37.0 \%$ in the samples sent by the emergency department, the positivity rate in anaerobic cultures was $20.5 \%$ throughout the hospital and $32.1 \%$ in the samples sent by the emergency department. Yücel et al. (4) reported the reproduction rate of blood cultures sent by the emergency department as $15 \%$ in their study. The most common pathogen in the blood culture samples was $S$. aureus (31.8\%) and the most common pathogen in anaerobic culture was S. aureus $(33.3 \%)$. This was followed by E. coli $(25.0 \%)$ in aerobic culture and $S$. hominis (27.3\%) in anaerobic culture. In the study of Yücel et al. (4), the most frequently detected pathogen was reported as coagulase-negative streptococci. In the study of Yürümez et al. (5), the most frequently detected pathogen in anaerobic blood culture was reported as E.coli, similar to our study. In the study carried out by Oğuz et al. (18) in pediatric emergency patients, $5.8 \%$ of the samples showed that there was a reproduction, $91.7 \%$ of this reproduction was gram-positive and $8.3 \%$ was Gram-negative bacteria. In the study of Karakoç et al. (19), it was reported that the rate of significant growth in blood cultures was $18.3 \%$. In the study conducted by Çetin et al. (8), a reproduction rate of $30 \%$ was detected in blood culture samples sent from intensive care patients and the most frequent pathogens were reported as coagulase-negative streptococci and less frequently A. baumannii. Similar studies have been conducted on the usefulness of blood culture in many different patient populations. A 2006 study suggests that the rate of beneficial cultures is $2.8 \%$ and that blood culture should be taken only in the case of urinary tract infection, community-acquired pneumonia, and cellulitis in people who are immunocompromised (20). In another study conducted in 2007 , it was stated that $6 \%$ of all culture samples had reproduction and only $0.18 \%$ of all patients changed the treatment process (20). In our study, there was no study on how much blood cultures directed treatment, and it is not possible to evaluate this in the emergency room as the culture results are concluded at the earliest 2 days later. Detailed studies on the value of the samples taken in the emergency departments and how much they direct the treatment will give more accurate results in this regard.

In the study, the rate of sterile body fluid culture positivity was $25.2 \%$ throughout the hospital and $27.3 \%$ in samples sent by the emergency department. The most common pathogens in culture samples were detected in the samples of $S$. aureus, E. coli, and S. agalactiae (16.0\%). In the study of Yücel et al. (4), the growth rate in sterile body fluid cultures sent from the emergency department was reported to be $16 \%$. In the study, the most common pathogen grown in culture samples taken from sterile body fluids was $S$. aureus (16.0\%), followed by E. coli and S. agalactiae (16.0\%). In the study conducted by Çetin et al. (8), a growth rate of $33.3 \%$ was found in sterile body fluid samples taken from patients in the intensive care unit, and the reproducing pathogens were reported as $S$. aureus, Enterobacteriaceae and $A$. baumannii.

In some studies, the most frequently isolated pathogen in soft tissue infections is known as $S$. aureus $(21,22)$. In our study, the rate of wound culture positivity was $64.3 \%$ throughout the hospital and $27.3 \%$ in samples sent by the emergency service. Yücel et al. (4) reported the growth rate in wound cultures sent from the emergency department as $61 \%$ in their study. In the culture samples taken from the wound, the most common pathogen was $S$. aureus (21.0\%), followed by $S$. epidermidis (16.0\%). Yücel et al. (4) reported the most common pathogen in wound cultures sent by the emergency service as E.coli and S. aereus. In our study, the rate of abscess culture positivity was $57.5 \%$ throughout the hospital and $63.6 \%$ in samples sent from the emergency service. Yücel et al. (4) reported that the growth rate in abscess cultures sent by the emergency service was $50 \%$. In our study, in the culture samples taken after abscess drainage, the most common pathogen was $S$. aureus (41.9\%), followed by $S$. pyogenes (12.9\%). Yücel et al. (4) reported $E$. coli as the most frequently detected bacterium in abscess cultures. In the study conducted by Çetin et al. (8), the most frequently grown pathogens in wound culture samples sent from patients in the intensive care unit were reported as coagulase-negative streptococci.

\section{Study Limitation}

The most important limitation in this study is that the study was performed in a single-center and retrospective manner; therefore, the symptoms and examination information of the patients could not be obtained. The data cover only adult emergency data, child emergency data are not included. In the study, antibiogram results of reproductive samples 
were not evaluated. Therefore, it is not possible to make any comments regarding the prophylactic antibiotic use recommendations. It is not known in which environment and how the cultures were taken and whether they were brought to the laboratory environment in appropriate conditions and time, and how long the cultivation was done after coming to the laboratory, and these could not be standardized since retrospective studies were performed. The patients' co-morbid diseases, immune suppression status, and other infective diseases, if any, have not been known, so the possible effects of co-morbid diseases on the culture growth of patients have not been evaluated.

\section{Conclusion}

Culture tests are frequently used in hospitals and emergency rooms. The pathogens isolated from the cultures differ according to the region, culture type, and disease type. Knowing the most frequently detected pathogens both in hospitals and in clinics is effective in prophylactic antibiotic use decisions and information is given to healthcare workers about the possible measures that may be required during the spread of possible hospital-borne or community-borne infections. The culture positivity rate was higher in the samples sent from the emergency rooms than in those in the general hospital. While culture positivity rate is high in wound and abscess cultures, it is very low in stool cultures. Detailed studies, including disease-based and antibiotic resistance of cultures sent from the emergency departments, will guide the initiation of prophylactic treatment. New studies on this subject are needed.

\section{Ethics}

Ethics Committee Approval: This study was planned retrospectively. It was started after the approval of the Ethics Planning Board numbered 2017/582 at the 49th Board Meeting held on 13.06.2017 from the Ethics Committee of the Turkish Republic Ministry of Health, University of Health Sciences Turkey, İstanbul Bağcılar Training and Research Hospital.

Informed Consent: Patient consent was obtained.

Peer-review: Externally peer-reviewed.

\section{Authorship Contributions}

Concept:Ş.Ö.H., İ.Ö., Design: Ş.Ö.H., M.A.K., Data Collection or Processing: M.A.K., İ.Ö., Analysis or Interpretation: S..Ö.H., M.A.K., Literature Search: Ş.Ö.H., Writing: Ş.Ö.H.

Conflict of Interest: No conflict of interest was declared by the authors.
Financial Disclosure: The authors declared that this study has received no financial support.

\section{References}

1. Long B, Koyfman A. Best clinical practice: blood culture utility in the emergency department. J Emerg Med 2016;51(5):529-539.

2. Baron EJ, Miller JM, Weinstein MP, Richter SS, Gilligan PH, Thomson Jr RB, et al. A guide to utilization of the microbiology laboratory for diagnosis of infectious diseases: 2013 recommendations by the Infectious Diseases Society of America (IDSA) and the American Society for Microbiology (ASM)(a). Clin Infect Dis 2013;57(4):e22-e121.

3. Ece Terek G, Tunçel Başoğlu M. The evaluation of the distribution and antimicrobial susceptibility profile of strains isolated from urine specimens at a university hospital. Ege J Med 2013;52(3):136140 .

4. Yücel N, Kuzucu Ç, Yetkin F, Tunç E. Enfeksiyon bulguları ile acil servis'e başvuran hastaların kültür sonuçlarının değerlendirilmesi. İnönü Üniv Tıp Fak Derg 2010;17(4):359-364.

5. Yürümez Y, Yavuz Y, Çiftçi İH, Kamil T, Kıyıldı N. How much is blood cultures valuable for adult emergency department patients? Turkey J Emerg Med 2005;5(3):118-121.

6. Grignon O, Montassier E, Corvec S, Lepelletier D, Hardouin JB, Caillon J, et al. Escherichia coli antibiotic resistance in emergency departments. Do local resistance rates matter? Eur J Clin Microbiol Infect Dis 2015;34(3):571-577.

7. Demographic Outlook. National reports on the demographic developments in 2010. Luxembourg: Publications Office of the European Union; 2012. Available at: https://ec.europa.eu/ eurostat/documents/3888793/5851529/KS-RA-12-004-EN.PDF/ f267d12b-d055-4959-884b-90c14d642d2d

8. Çetin ES, Kaya S, Pakbaș İ, Demirci M. Yoğun bakım ünitelerinde yatan hastalardan izole edilen mikroorganizmalar ve antibiyotik duyarlılıkları. J Turgut Özal Med Cent 2007;14(2).

9. Ertürk A, Çiçek AÇ, Köksal E, Köksal ZŞ, Özyurt S. Microorganisms, and antibiotic susceptibilities isolated from various clinical samples of patients hospitalized in the intensive care unit. Ankem Journal 2012;26(1):1-9.

10. Humphreys $\mathrm{H}$. Controlling the spread of vancomycin-resistant enterococci. Is active screening worthwhile? J Hosp Infect 2014;88(4):191-198.

11. Silva CD, Silva Junior M. Strategies for appropriate antibiotic use in the intensive care unit. Einstein (Sao Paulo) 2015;13(3):448-453.

12. Talay F, Çetinkaya E, Gençoğlu A, Şafak G, Taş I, Altın S, et al. Nonspecific culture antibiogram results, and empirical treatment approaches in inpatients due to lower respiratory infection. Abant Med J 2014;3(1):21-26.

13. Güney M, Başustaoğlu AC. Investigation of the location of campylobacter jejuni and campylobacter coli and their susceptibility to antimicrobials among the acute bacterial gastroenteritis factors in Gülhane Military Medical Academy Training Hospital. Turk J Microbiol 2010;40(3):183-192.

14. Yetkin G, Kılıç S, Söylemez H, Altunoluk B, Çalışkan A. Altı aylık periyodda üroloji klinik ve polikliniğine üriner enfeksiyon öntanısıyla başvuran hastaların semptom ve laboratuvar profili yönünden incelenmesi. Abant İzzet Baysal Med J 2009;4(2):11-14. 
15. Ece Dağlar D, Demirbakan H, Yıldırım Ç, Öztürk F, Özcan A, Sipen N, et al. Bacteria isolated from urine samples and their susceptibility to antibiotics. Türk Mikrobiyol Cem Derg 2005;35(3):189-194.

16. Ergin ÖY, Afşar İ, Karaayak Uzun B, Kurultay N, Yurtsever SG, Türker M. Evaluation of intravascular catheter cultures in patients in intensive care units. Ankem Derg 2006;20(2):94-97.

17. Sünbül M, Bitirgen M, Arıbaş ET. Çeşitli klinik tanılarla izlenen hastalarda subklavian kateter kültür sonuçlarının değerlendirilmesi. SDU Faculty of Med J 1995;2(3).

18. Oğuz S, Kurt F, Korkmaz V, Tekin D, Suskan E. Çocuk Acil Servisinde Kan Kültürü Kullanımı. Turk J Pediatr 2016;10(4):265-269.
19. Karakoç AE, Ayyorgun Ş, Yücel M, Gündüz E. Bir yıllık kan kültürü sonuçlarının mikrobiyolojik değerlendirilmesi. J Int Med Sci 2006;13(2):101-106.

20. Mountain D, Bailey PM, O’Brien D, Jelinek GA. Blood cultures ordered in the adult emergency department are rarely useful. Eur J Emerg Med 2006;13(2):76-79.

21. Abrahamian FM, Talan DA, Moran GJ. Management of skin and soft-tissue infections in the emergency department. Infect Dis Clin North Am 2008;22(1):89-116, vi.

22. Frazee BW, Lynn J, Charlebois ED, Lambert L, Lowery D, Perdreau-Remington F. High prevalence of methicillin-resistant staphylococcus aureus in emergency department skin and soft tissue infections. Ann Emerg Med 2005;45(3):311-320. 